\title{
The Morphogenic/Cytotoxic and Prostaglandin-stimulating Activities of Interleukin-1 $\beta$ in the Rat Ovary Are Nitric Oxide Independent
}

\author{
I. Ben-Shlomo, * E. Y. Adashi, and D. W. Payne \\ Division of Reproductive Endocrinology, Departments of Obstetrics/Gynecology and Physiology, University of Maryland at Baltimore, \\ Baltimore, Maryland 21201; and the Rebecca Sieff Hospital, Safed, Israel
}

\begin{abstract}
Nitric oxide (NO) has been implicated as a mediator of physiologic and pathologic cellular injury. Since the cyto-

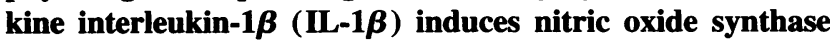
(NOS) activity as well as effects morphogenic/cytotoxic changes and increased prostaglandin ( PGE $_{2}$ ) levels in cultured whole ovarian dispersates, we set out to determine whether these actions are interrelated. Treatment with IL$1 \beta$ resulted in a marked increase in media nitrite and nitrate accumulation, morphological alterations, and increased release of lactate dehydrogenase (LDH) into media. Addition

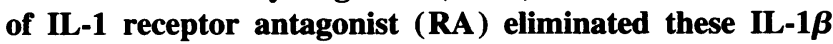
effects. In contrast, specific inhibitors of NOS failed to reverse IL-1 $\beta$-induced morphogenic changes or $L D H$ release in spite of complete reduction of media nitrite to control levels. Similarly, treatment with transforming growth factor

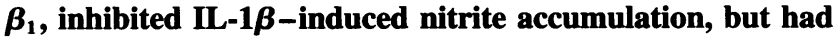
no effect on the morphologic or cytotoxic endpoints. Moreover, the addition of sodium nitroprusside, an NO generator, resulted in progressive increments in media nitrite content without a corresponding increase in the $\mathrm{IL}-1 \beta$-associated morphogenic changes or media LDH content. Furthermore, IL-1-induced $\mathrm{PGE}_{2}$ accumulation remained unaffected by specific NOS inhibition. These observations support the view that NO does not mediate the morphogenic/cytotoxic or inflammatory-like (e.g., $\mathrm{PGE}_{2}$ inducing) properties of $\mathrm{IL}$ $1 \beta$ in cultured whole ovarian dispersates. Although the precise role of $\mathrm{NO}$ in ovarian physiology remains unknown, it is possible that NO participates in the periovulatory modulation of ovarian blood flow by virtue of its potent vasodilatory activity. (J. Clin. Invest. 1994. 94:1463-1469.) Key words: interleukin-1 - nitric oxide $\cdot$ prostaglandins $\cdot$ nitric oxide inhibitors - rat ovary
\end{abstract}

\section{Introduction}

The free radical gas, nitric oxide (NO), ${ }^{1}$ the subject of intense multidisciplinary investigation, is a labile messenger molecule

Address correspondence to Dr. Donna W. Payne or Dr. Eli Y. Adashi, Division of Reproductive Endocrinology, Department of Obstetrics and Gynecology, University of Maryland School of Medicine, $655 \mathrm{~W}$. Baltimore Street, BRB 11-011, Baltimore, Maryland, 21201.

Received for publication 16 February 1994 and in revised form 13 June 1994.

1. Abbreviations used in this paper: AG, aminoguanidine; iNOS, inducible form of nitric oxide synthase; LDH, lactate dehydrogenase; MLA, $\mathrm{N}^{\mathrm{G}}$-monomethyl-L-arginine; NO, nitric oxide; RA, IL- $1 \beta$ receptor antagonist.

J. Clin. Invest.

(C) The American Society for Clinical Investigation, Inc. 0021-9738/94/10/1463/07 $\$ 2.00$

Volume 94, October 1994, 1463-1469 in multiple tissues. It is formed from L-arginine by nitric oxide synthase (NOS), a family of distinct gene products (1-3). Among its multiple actions, NO has been implicated as an effector in physiologic and pathologic cellular injury $(1,3)$. The cytotoxic, cytostatic and mutagenic properties of NO are largely due to the crippling formation of iron/sulfur-nitrosyl complexes in key enzymes associated with DNA synthesis and cellular respiration. Formation of reactive nitrogen intermediates and the stimulation of cGMP signaling may also be involved $(1,3,4)$. NO has been shown to induce macrophage death by apoptosis (5) and to cause DNA damage and mutation in a human cell line (6).

A role for NO, formed by the action of the inducible isoform of NOS (iNOS), in the mediation of activated macrophageinduced cytotoxicity is well established $(7,8)$. Although iNOS (in contrast to constitutive forms which mediate vasodilation and neurotransmission), have been found in multiple, nonphagocytic tissues (1), their role in these tissues is less clear. A variety of inflammatory cytokines, of which interleukin-1 (IL-1) is one, induce NO formation. IL-1-induced NO formation suppresses the beating rate of cultured cardiac myocytes (9), occurs in vascular smooth muscle (10), and inhibits insulin secretion by pancreatic islet cells $(11,12)$.

It is against this backdrop that we set out to determine whether NO generation plays a role in the morphogenic/cytotoxic (13) and prostaglandin-stimulatory (14) activities of IL1 in cultured rat whole ovarian dispersates. That this may in fact be the case has been suggested by our recent demonstration of the potent ability of IL- $1 \beta$ to stimulate ovarian iNOS activity (15). While this manuscript was in preparation, Ellman et al. (16) suggested that the cytotoxic effects of IL- $1 \beta$ in the ovary are mediated by NO. Our present findings do not support this conclusion but rather suggest that the morphogenic/cytotoxic (13) and the prostaglandin stimulatory activities (14) of IL-1 in the rat ovary are NO independent.

\section{Methods}

Materials and hormones. Recombinant human IL- $1 \beta\left(2 \times 10^{7} \mathrm{U} / \mathrm{mg}\right)$ was generously provided by Drs. Errol B. De Souza and C. E. Newton of DuPont-Merck Pharmaceutical Co. (Wilmington, DE). Recombinantlyexpressed, naturally occurring human IL- $1 \beta$ receptor antagonist (RA; 17) was generously provided by Dr. Daniel E. Tracey (The Upjohn Co, Kalamazoo, MI). Transforming growth factor $\beta_{1}$ (TGF $\left.\beta_{1}\right)$ was generously provided by Dr. J. P. Mather (Genentech, San Francisco, CA). McCoy's 5a medium (without serum), penicillin-streptomycin solution, L-glutamine, trypan blue stain and bovine serum albumin were obtained from GIBCO BRL (Grand Island, NY). Collagenase (Clostridium Histolyticum; CLS type I; $144 \mathrm{U} / \mathrm{mg}$ ) was from Worthington Biochemical Corp. (Freehold, NJ). DNAse (bovine pancreas), lactate dehydrogenase (LDH) assay kits, sodium nitroprusside, sulfanilamide, $N$ (1-naphthyl)ethylenediamine dihydrochloride, phosphoric acid $\mathrm{NaNO}_{2}$ and aminoguanidine hemisulfate salt (AG) were from Sigma Chemical Co. (St. Louis, MO). $\mathbf{N}^{\mathbf{G}}$-monomethyl-L-Arginine Monoacetate (MLA) was obtained from Calbiochem Corp. (San Diego, CA). 
Tissue culture. Immature (25-28 d old) Sprague-Dawley female rats were purchased from Zivic-Miller Laboratories (Zelienopole, PA). Whole ovarian dispersates $\left(5 \times 10^{5}\right.$ viable cells/dish) were prepared as previously described (18). Cells were inoculated onto $35 \times 10 \mathrm{~mm}$ tissue culture dishes (Falcon Plastics, Oxnard, CA) containing $1 \mathrm{ml}$ of McCoy's 5 a medium (modified, without serum) containing L-arginine$\mathrm{HCl}(0.24 \mathrm{mM})$. Media were supplemented with L-glutamine ( $2 \mathrm{mM})$, penicillin $(100 \mathrm{U} / \mathrm{mL})$, and streptomycin $(100 \mu \mathrm{g} / \mathrm{mL})$. Cell cultures were maintained for $96 \mathrm{~h}$ at $37^{\circ} \mathrm{C}$ under a water-saturated atmosphere of $5 \% \mathrm{CO}_{2}$ and $95 \%$ air. Stocks of IL- $1 \beta(500 \mathrm{ng} / \mathrm{ml}), \mathrm{RA}(1.1 \mathrm{mg} /$ $\mathrm{ml}$ ) and NOS inhibitors ( $4 \mathrm{mM}$ ) were prepared in sterile culture medium and stored at $-20^{\circ} \mathrm{C}$ until thawed and diluted in sterile culture medium for addition to cultures at the time of plating. At the end of each experiment collected media were immediately assayed for LDH activity and/ or stored at $-20^{\circ} \mathrm{C}$ until assayed for nitrite/nitrate, or prostaglandin $\mathrm{E}_{2}$ $\left(\mathrm{PGE}_{2}\right.$ ) content as described below.

Nitrite and nitrate assays. Nitrite concentrations in conditioned media were determined by a previously described colorimetric method ( 7 , 19) adapted and miniaturized by us to a microtiter plate system. Greiss Reagent was prepared fresh daily by mixing equal volumes of Stock A ( $10 \%$ sulfanilamide, $40 \%$ phosphoric acid) and Stock B (1\% N 1 naphthyl] ethylenediamine dihydrochloride in distilled water), both stored at $4^{\circ} \mathrm{C}$. For the assay, conditioned media were thawed and appropriate quantities were added to each microtiter plate well, along with $25 \mu \mathrm{l}$ of Greiss Reagent and unconditioned medium to bring the final volume to $200 \mu \mathrm{l}$. Absorbance at $570 \mathrm{~nm}$ (70\% of the maximum absorbance of $545 \mathrm{~nm}$ ) was read at ambient temperature in a UVmax microtiter plate reader (Molecular Devices, Menlo Park, CA). Nitrite concentrations were calculated using a software package $(\Delta$ Soft, BioMetallics, Inc., Princeton, NJ) designed for this device, against a standard curve for $\mathrm{NaNO}_{2}$. The stock solution $(100 \mu \mathrm{M})$ for $\mathrm{NaNO}_{2}$ was prepared in McCoy 5 a medium and stored at $-20^{\circ} \mathrm{C}$.

Total nitrate plus nitrite content was determined by Greiss assay as above following enzymatic conversion of media nitrates to nitrites using our modification of a previously described method (20). Specifically, conditioned media $(100 \mu \mathrm{l})$, or $\mathrm{NaNO}_{3}$ standard were incubated overnight at room temperature in a buffer ( final volume $=200 \mu \mathrm{l}$ ) containing as follows (final concentration): potassium phosphate $(40 \mathrm{mM} ; \mathrm{pH}$ 7.4), EDTA (0.45 mM), DTT ( $0.45 \mathrm{mM})$, sucrose (110 mM), NADPH $(0.25 \mathrm{mM})$ and nitrate reductase $(10 \mathrm{mU})$ from Aspergillus (Sigma Chemical Co., St. Louis, MO). Under these conditions the standard curves for $\mathrm{NaNO}_{2}$ and reduced $\mathrm{NaNO}_{3}$ were nearly identical confirming that nitrates were completely converted to nitrites.

Lactate dehydrogenase ( $L D H)$ assay. $\mathrm{LDH}$ leakage into media was taken as an indication of compromised membrane integrity (21) and was determined by conversion of lactate to pyruvate in the presence of NAD. The rate of NADH production was monitored by absorbance at $340 \mathrm{~nm}$ in a UVmax kinetic microtiter plate reader (Molecular Devices). Premixed reagents (LD-L Kit; Sigma Chemical Co.) were adapted by us for use in this miniaturized system as follows. Freshly collected conditioned media were diluted 10-fold in LDH assay solution (final volume $=200 \mu \mathrm{l}$ ) and absorbance at $340 \mathrm{~nm}$ was immediately monitored at $1 \mathrm{~min}$ intervals for $30 \mathrm{~min}$. The assay was linear with media volume up to about $15 \mathrm{mOD} / \mathrm{min}$ (equivalent to approximately $5 \mathrm{mU} /$ $\mathrm{ml}$ of a commercial LDH standard). In this system, an absorbance of $2963 \mathrm{mOD}$ per mM NADH was observed which is $90 \%$ of the predicted value based on the molar extinction coefficient of NADH $(0.53 \mathrm{~cm}$ path length). LDH activity was calculated based on this NADH conversion factor where one unit is equivalent to $1 \mu \mathrm{mol} \mathrm{NADH}$ produced per minute.

Prostaglandin- $E_{2}\left(P G E_{2}\right)$ radioimmunoassay. Media $\mathrm{PGE}_{2}$ content was measured using a specific radioimmunoassay with $\mathrm{PGE}_{2}$-directed antisera (22) generously provided by Dr. Harold R. Behrman (Yale University, New Haven, CT).

Morphologic assessment. Photomicrographs of cultured cells $(\times 200)$ were taken with a phase contrast microscope (Olympus Model IMT-2, Cherry Hill, NJ) fitted with Hoffman optics.

Data analysis. Each experiment represents duplicate assays of triplicate cultures. Each such experiment was replicated a minimum of three

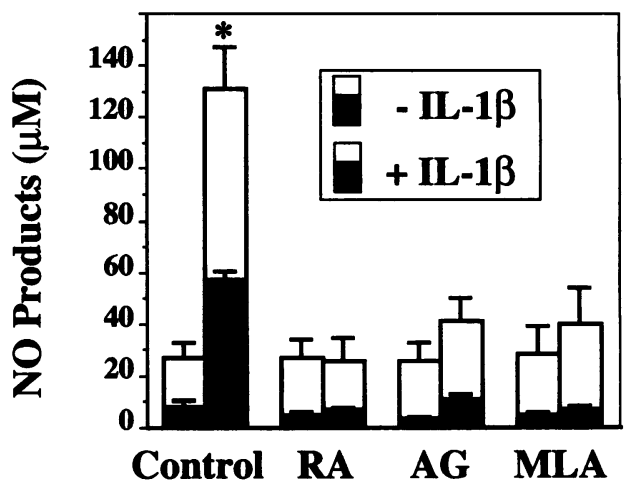

Figure 1 . Inhibition of IL-1 $\beta$-stimulated NO generation by IL-1 receptor antagonist and by inhibitors of iNOS. Whole ovarian dispersates ( 5 $\times 10^{5}$ viable cells/dish) were cultured for $96 \mathrm{~h}$ under serum-free conditions in the absence or presence of IL- $1 \beta(50 \mathrm{ng} / \mathrm{ml})$, with or without IL-1 RA $(5 \mu \mathrm{g} / \mathrm{ml})$, AG $(0.4 \mathrm{mM})$, or MLA $(0.4 \mathrm{mM})$. Media nitrate (open bars) and nitrite (solid bars) content were measured as described in Methods. Results represent the mean \pm SE of 3-5 separate experiments. Significance by ANOVA analysis for both nitrates and nitrites (relative to the $-\mathrm{IL}$ control) is noted $(*)$.

times. Data points are presented as mean $\pm \mathrm{SE}$ and statistical significance (Fisher's Protected Least Significant Difference) was determined by ANOVA analysis as noted in the text and legends. Statistical values were calculated using Statview 512+ for MacIntosh (Brain Power, Inc., Calabasas, CA). Statistical significance $(P<0.05)$ is denoted in figures $(*)$.

\section{Results}

IL-1 $\beta$-stimulated NO generation is blocked by an $I L-1$ receptor antagonist and by inhibitors of NOS. Whole ovarian dispersates were cultured for $96 \mathrm{~h}$ under serum-free conditions in the absence or presence of $I L-1 \beta$, with or without the $I L-1$ receptor antagonist (RA), or specific inhibitors $(11,23-25)$ of iNOS, aminoguanidine (AG) and $\mathrm{N}^{\mathrm{G}}$-monomethyl-L-arginine (MLA). As shown (Fig. 1), treatment with $\mathrm{IL}-1 \beta$ resulted in 7- and 4fold increases over control in the accumulation of the stable products of labile NO (nitrites, solid bars; nitrates, open bars, respectively). Addition of RA eliminated the IL-1 effect. Comparable inhibition was observed after the application of optimal concentrations $(0.4 \mathrm{mM})$ of AG or MLA, both putative inhibitors of iNOS $(11,23-25)$. These findings indicate that the ability of IL-1 to promote ovarian NO generation is receptormediated and that iNOS may be involved. In addition, these observations reveal a comparable pattern of accumulation for nitrites and nitrates suggesting that analysis of nitrite accumulation alone (as used below) adequately reflects NO production.

NO does not mediate $I L-1 \beta$-induced morphogenic/cytotoxic alterations in cultured whole ovarian dispersates. To examine the possibility that NO may mediate the previously described (13) morphogenic/cytotoxic actions of IL- $1 \beta$ in the rat ovary, whole ovarian dispersates were cultured for $96 \mathrm{~h}$ under serum-free conditions in the absence or presence of $\mathrm{IL}-1 \beta$, with or without RA (Fig. 2) or maximal doses (see Fig. 1) of iNOS inhibitors (Fig. 3). Treatment with IL-1 $\beta$ (Fig. $2 B$ ) resulted in the same marked morphological alterations (cellular retraction, clumping and aggregation) which we described previously in detail (13). The typical morphogenic outcome (e.g., morphogenic effect) of IL- $1 \beta$ action (i.e., clumps of cells which can 

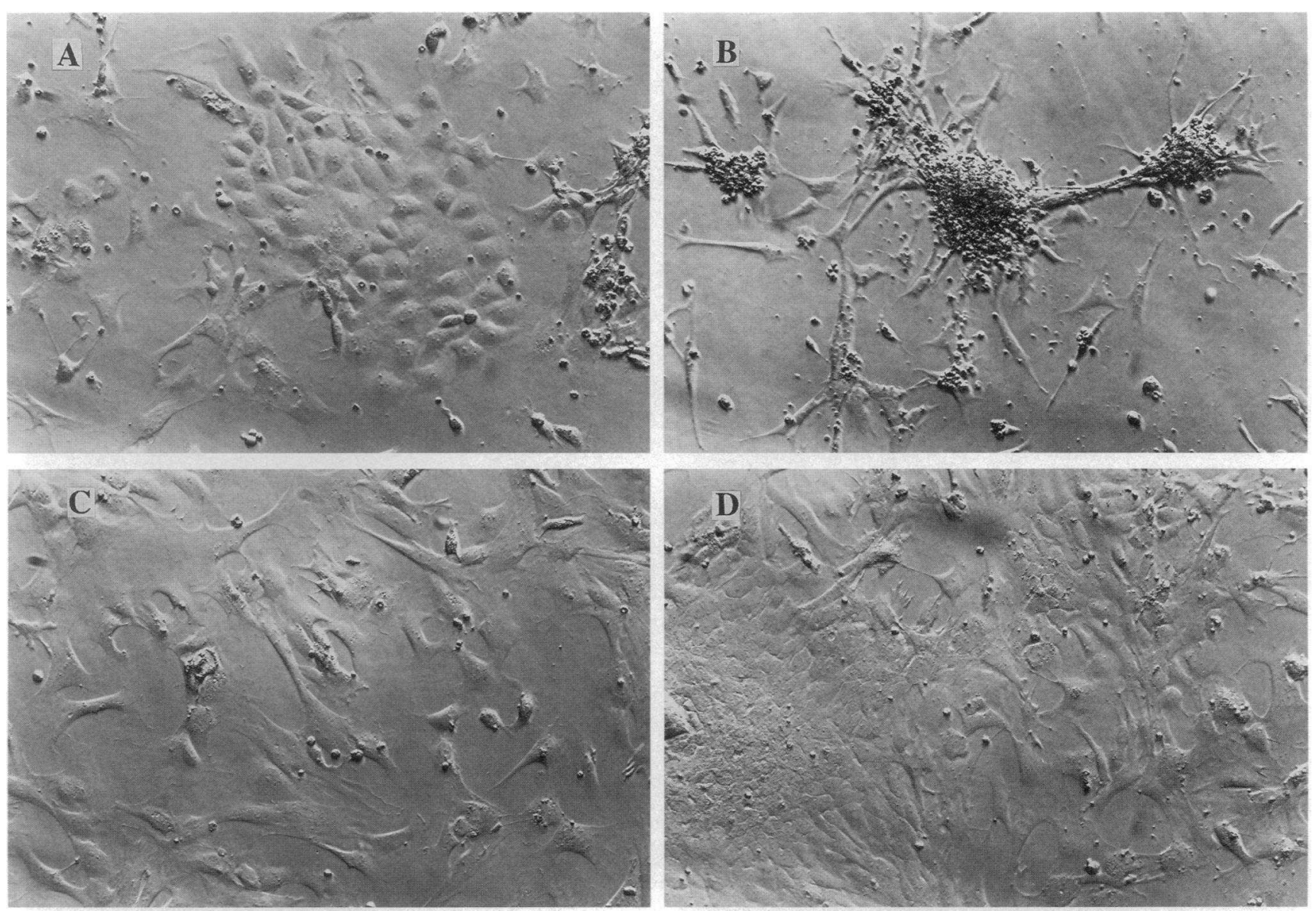

Figure 2. IL-1 $\beta$-induced morphogenic/cytotoxic alterations in cultured whole ovarian dispersates are IL-1 receptor-mediated. Whole ovarian dispersates $\left(5 \times 10^{5}\right.$ viable cells $/$ dish $)$ were cultured for $96 \mathrm{~h}$ under serum-free conditions in the absence or presence of $\mathrm{IL}-1 \beta(50 \mathrm{ng} / \mathrm{ml})$, with or without IL-1 RA (5 $\mu \mathrm{g} / \mathrm{ml})$. (A) Control; (B) IL-1 $\beta$; (C) RA; (D) IL-1 $\beta$ + RA. Data reflect a representative experiment.

be seen as dark areas in Fig. $2 B$ ) represents an intermediary phase which ultimately leads to injury and/or lifting of cells from the dish (e.g., cytotoxic effect). Concurrent provision of RA eliminated these changes (Fig. $2 \mathrm{D}$ ). In contrast, addition of AG (Fig. $3 B$ ) or MLA (Fig. $3 D$ ) failed to reverse the morphologic effects of IL- $1 \beta$ in the face of a marked reduction in the accumulation of NO products (Fig. 1). Taken together, these observations argue against the possibility that the morphogenic/cytotoxic effects of IL-1 $\beta$ (see Fig. $2 B$ ) require the intermediacy of NO.

To further assess the possible role of NO in the ability of IL-1 $\beta$ to exert a morphogenic/cytotoxic effect, media LDH levels were measured. Leakage of cytosolic $\mathrm{LDH}$ into media is an accepted marker of diminished membrane integrity (21) and is one of several functional endpoints of $\mathrm{IL}-1 \beta$-induced cytotoxicity which we have described previously (13). Treatment with IL- $1 \beta$ produced a nearly twofold increase over baseline in the extracellular accumulation of LDH (Fig. 4). Basal levels of extracellular LDH activity presumably represent inherent cellular damage associated with the culture system under study. Concurrent addition of RA produced complete reversal of this IL- $1 \beta$ effect. In contrast, the addition of AG or MLA failed to reverse the $\mathrm{IL}-1 \beta$-stimulated accumulation of LDH (not significantly different from IL- $\beta$ alone) despite marked decrements in the generation of NO products (see Fig. 1). To the extent that LDH constitutes an acceptable marker of cellular cytotoxicity, the present findings argue against an intermediary role of NO in the ability of IL- $1 \beta$ to effect cytotoxic alterations in cultured rat whole ovarian dispersates.

Since TGF $\beta_{1}$ has been shown to inhibit the NO-mediated effects of IL- $1 \beta$ in cardiac myocytes (9), we examined whether IL- $1 \beta$-mediated nitrite production in the ovary could be reversed by TGF $\beta_{1}$. As shown (Fig. 5, top panel), IL- $1 \beta$-induced nitrite production in whole ovarian dispersates is inhibited by $\mathrm{TGF} \beta_{1}$ in a dose-dependent fashion, with an $\mathrm{EC}_{50}$ of $2.7 \mathrm{ng} / \mathrm{ml}$ and maximal inhibitory effect $(98 \%)$ at the $50 \mathrm{ng} /$ $\mathrm{ml}$ dose level. In spite of the complete inhibition of nitrite accumulation by TGF $\beta_{1}$ (Fig. 5, top panel), neither the IL- $1 \beta-$ induced increase in media LDH levels (Fig. 5, bottom panel) nor the IL-1-associated morphologic changes (not shown) were reversed by TGF $\beta_{1}$. That is, no significant (ANOVA analysis) inhibitory changes were observed for any $\operatorname{TGF} \beta$ dose in the presence of IL- $1 \beta$, compared with IL- $1 \beta$ alone.

To further assess a possible role of NO in the induction of the morphogenic/cytotoxic changes observed with IL- $1 \beta$ treatment, whole ovarian dispersates were cultured for $96 \mathrm{~h}$ under serum-free conditions in the absence or presence of increasing concentrations of sodium nitroprusside $(0.05-0.5 \mathrm{mM})$, an NO generator. As shown (Fig. 6, top panel), the provision of increasing concentrations of sodium nitroprusside resulted in progressive, significant $(*)$ increments in the nitrite content of conditioned media. Importantly, regardless of the sodium nitro- 


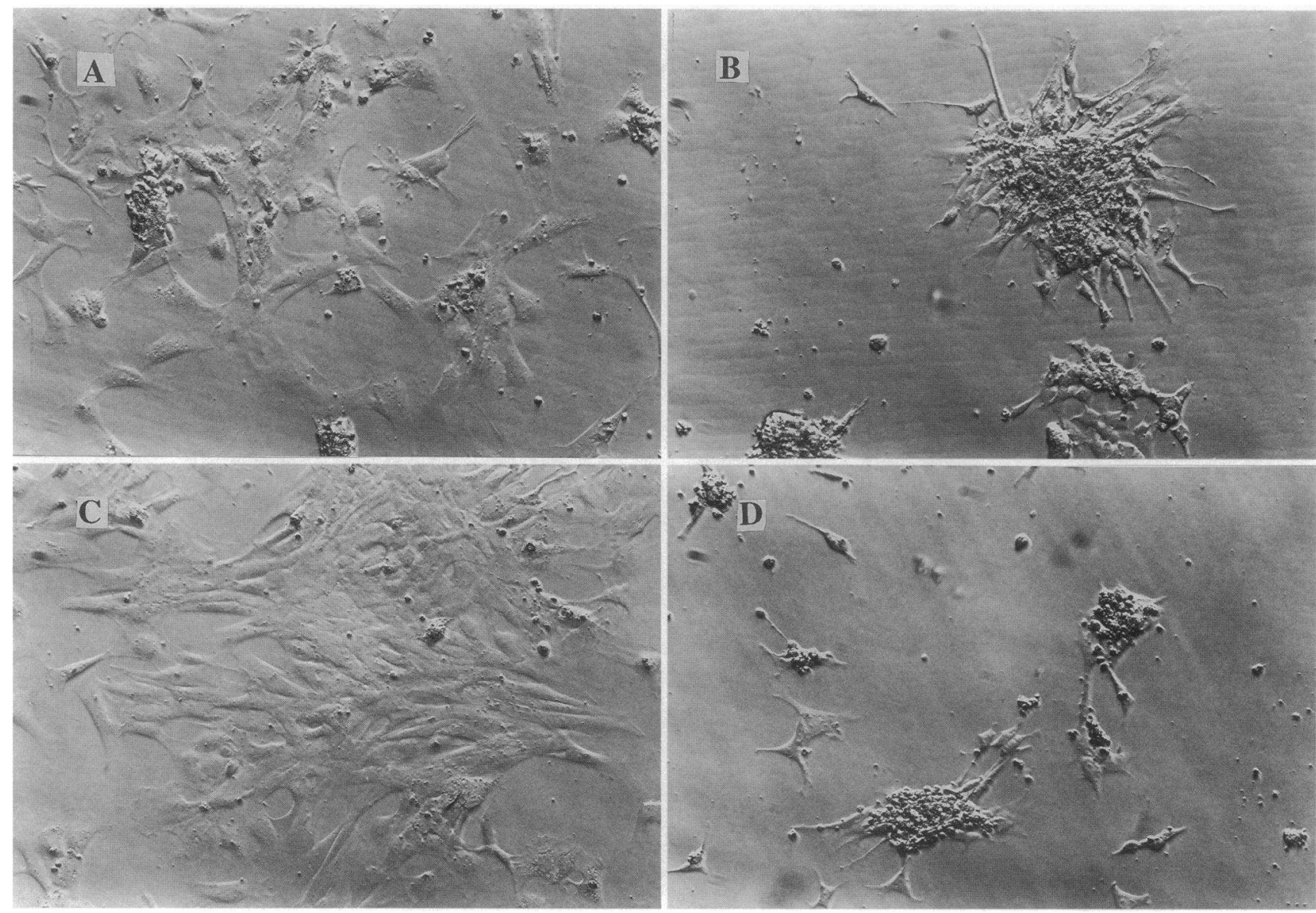

Figure 3. IL-1 $\beta$-induced morphogenic/cytotoxic alterations in cultured whole ovarian dispersates are not reversed by iNOS inhibitors. Whole ovarian dispersates $\left(5 \times 10^{5}\right.$ viable cells/dish) were cultured for $96 \mathrm{~h}$ under serum-free conditions in the absence or presence of IL-1 $\beta$ ( $50 \mathrm{ng} /$ $\mathrm{ml})$, with aminoguanidine $(0.4 \mathrm{mM})$ or MLA $(0.4 \mathrm{mM})$. (A) AG; $(B) \mathrm{IL}-1 \beta+\mathrm{AG} ;(C) \mathrm{MLA} ;(D) \mathrm{IL}-1 \beta+$ MLA. Data reflect the same representative experiment as shown in Fig. 2.

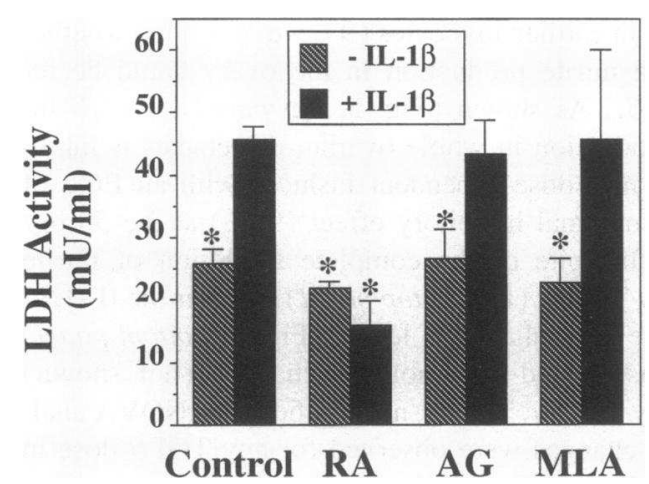

Figure 4. IL- $1 \beta$-induced cytotoxic LDH release is not reversed by iNOS inhibitors. Whole ovarian dispersates $\left(5 \times 10^{5}\right.$ viable cells $/$ dish) were cultured for $96 \mathrm{~h}$ in the absence or presence of IL-1 $\beta$ ( $50 \mathrm{ng} / \mathrm{ml})$, with or without IL-1 RA $(5 \mu \mathrm{g} / \mathrm{ml})$, AG $(0.4 \mathrm{mM})$, or MLA ( $0.4 \mathrm{mM})$. Media LDH activity was determined as described in Methods. Data reflect the mean $\pm S E$ of 3-4 separate experiments. Significance by ANOVA analysis relative to the + IL$1 \beta$ control is noted $(*)$. Results were also significant (not shown) for the AG and MLA treatments, comparing each $-\mathrm{IL}-1 \beta$ to $+\mathrm{IL}-1 \beta$. prusside dose, the media content of nitrites associated with cultured whole ovarian dispersates proved substantially higher than those measured in the absence of cultured cells (Fig. 6, top panel, dashed line ). These observations suggest that the exogenously added sodium nitroprusside was processed intracellularly to yield increasing (cell dependent) concentrations of free measurable nitrite. However, despite the establishment of media nitrite concentrations in excess of those observed following stimulation with IL-1 $\beta$ (Fig. 1), no significant increase (by ANOVA analysis; $P=0.89$ ) was noted for the $\mathrm{LDH}$ content (Fig. 6, bottom panel) of the corresponding media. Furthermore, no IL-1-like morphologic changes were observed when nitroprusside (maximal NO-producing dose) was added to the media (Fig. 7, and see Fig. 2, $A$ and $B$ ). Taken together, these observations fully support the view that NO does not constitute a cytotoxic messenger in cultured rat whole ovarian dispersates.

$N O$ does not mediate IL-1 $\beta$-stimulated PGE biosynthesis. To examine the possibility that NO may mediate the property of IL-1 $\beta$ to induce inflammatory prostanoids (14) in the rat ovary, whole ovarian dispersates were cultured for $96 \mathrm{~h}$ in the absence or presence of $I L-1 \beta$, with or without $\mathrm{RA}, \mathrm{AG}$, or MLA. As shown (Fig. 8), treatment with $I L-1 \beta$ resulted in a fivefold increase over baseline in the accumulation of $\mathrm{PGE}_{2}$ as expected (14). The concurrent provision of RA yielded complete reversal of the IL- $1 \beta$ effect. In contrast, the addition of 


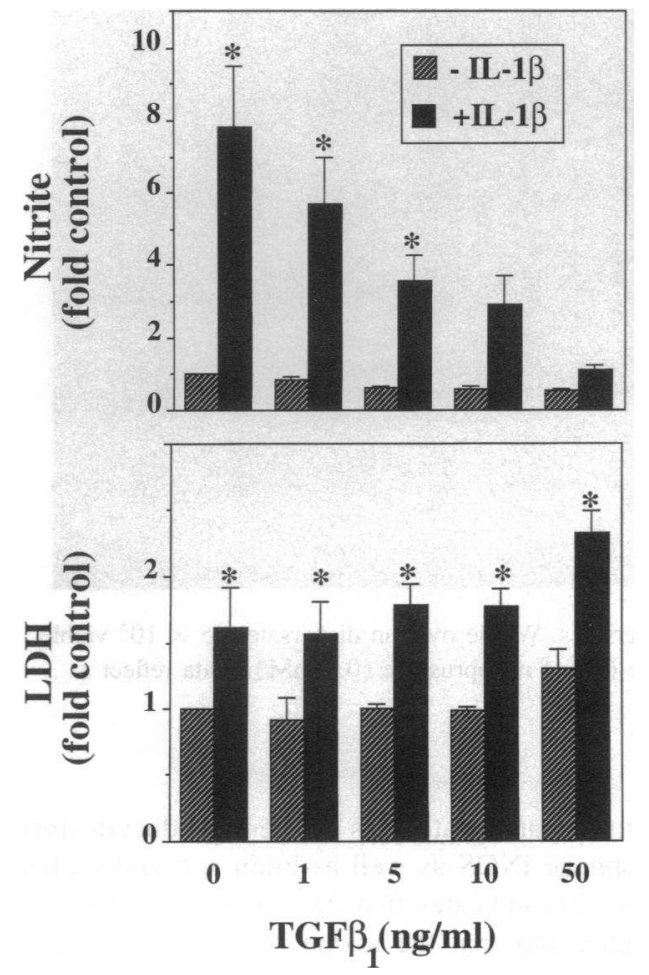

Figure 5. TGF $\beta_{1}$ antagonizes IL- $\beta$-induced nitrite formation but not IL- $1 \beta$-induced cytotoxic $\mathrm{LDH}$ release. Whole ovarian dispersates ( 5 $\times 10^{5}$ viable cells/dish) were cultured for $96 \mathrm{~h}$ in the absence or presence of IL-1 $\beta(50 \mathrm{ng} / \mathrm{ml})$ and increasing quantities $(0.5-50 \mathrm{ng} /$ $\mathrm{ml}$ ) of TGF $\beta_{1}$. Media were assayed for nitrite (top panel) or LDH activity (bottom panel). Data reflect mean $\pm S E$ of 3-4 experiments. Data are normalized to the control values, designated 1 , for each experiment. The actual mean control values are $10 \pm 3.2 \mu \mathrm{M}$ for nitrite (top panel) and $16.4 \pm 1.4 \mathrm{mU} / \mathrm{ml}$ for LDH activity (bottom panel). Significance by ANOVA analysis relative to the $-\mathrm{IL}-1 \beta$ alone is noted (*).

putative inhibitors of iNOS (AG or MLA) failed to reverse the IL- $1 \beta$-stimulated accumulation of $\mathrm{PGE}_{2}$ despite marked decrements in the generation of NO products (Fig. 1). These findings argue against an intermediary role of NO in the prostaglandin-stimulating property of $\mathrm{IL}-1 \beta$ in cultured rat whole ovarian dispersates.

\section{Discussion}

We have previously reported (13) that IL- $1 \beta$ exerts specific dose- and time-dependent morphogenic/cytotoxic effects in cultured rat whole ovarian dispersates, an effect characterized by cellular retraction, rounding, clumping, aggregation, blebbing, swelling, and ultimately, detachment. In that same experimental system we have shown (14) that IL- $1 \beta$ induces the formation of $\mathrm{PGE}_{2}$, a well-known mediator of inflammation. These observations coupled with our recent demonstration of the potent ability of IL- $1 \beta$ to stimulate the activity of ovarian iNOS (15), prompted us to determine whether NO generation, otherwise a common cytotoxic mediator $(7,8)$ of macrophage action, might in fact mediate the morphogenic/cytotoxic and inflammatorylike actions of $I L-1 \beta$ in the rat ovary.

Our present findings demonstrate that putative inhibitors of iNOS failed to affect the morphogenic/cytotoxic and prostaglandin-stimulating activities of $\mathrm{IL}-1 \beta$ in the face of a marked
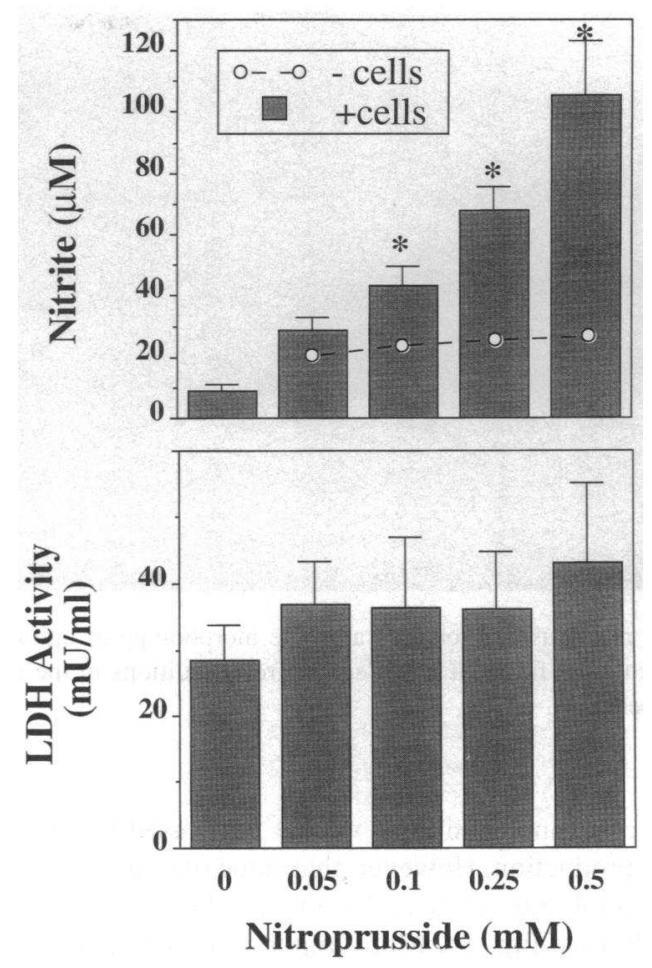

Figure 6. Sodium nitroprusside does not increase LDH release in cultured whole ovarian dispersates. Whole ovarian dispersates $\left(5 \times 10^{5}\right.$ viable cells/dish), or cell-free cultures (dashed line, upper panel) were carried for $96 \mathrm{~h}$ under serum-free conditions in the absence or presence of increasing concentrations of sodium nitroprusside $(0.05-0.5 \mathrm{mM})$. Media nitrite (upper panel) and LDH activity (lower panel) were determined as described in Methods. Data reflect the mean \pm SE of 3-4 experiments; ( $N=1$ for no cells). Significance by ANOVA analysis relative to the control (no nitroprusside) is noted (*).

inhibition of ovarian NOS activity. Specifically, RA (Fig. 1), iNOS inhibitors (AG, MLA; Fig. 1) and TGF $\beta_{1}$ (Fig. 5) all inhibited IL- $1 \beta$-induced nitrite and nitrate accumulation. As expected, the IL-1 $\beta$ actions on morphology (Fig. 2), cytotoxicity (Fig. 4) and $\mathrm{PGE}_{2}$ accumulation (Fig. 8) were receptor mediated since they were reversed by the specific receptor antagonist. In marked contrast, none of these $\mathrm{IL}-1 \beta$ effects could be overcome by iNOS inhibitors (Figs. 3,4 , and 8 ) or TGF $\beta_{1}$ (Fig. 5). The reverse experiment, i.e., addition of the NOgenerator, nitroprusside, confirmed the lack of role for NO in the IL- $1 \beta$-induced cytotoxic/morphologic changes. That is, application of exogenous NO (Fig. 6, upper panel) did not elicit the typical cytotoxic LDH response (Fig. 6, lower panel) or the morphogenic changes (Fig. $2 B$ vs Fig. 7) associated with IL-1 $\beta$ application.

Our data are in disagreement with those of Ellman et al. (16), who conclude that nitric oxide mediates IL- $1 \beta$-induced cellular cytotoxicity in the rat ovary based on their observation that $A G$ reverses the $I L-1 \beta$-induced release of $L D H$ into the culture medium. In contrast, we show (Fig. 4) that LDH release is not reversed by AG (or by another NOS inhibitor, MLA) although it is reversed by RA which serves as a positive control. The reason (s) for the apparent discrepancy is not clear although Ellman et al. (16) made use of a lower cell density $\left(2 \times 10^{5}\right.$ cells) as distinct from the cell density $\left(5 \times 10^{5}\right.$ cells $)$ used herein for which morphologic changes can be more reproducibly observed (13). Ellman et al. (16) also used a slightly higher 

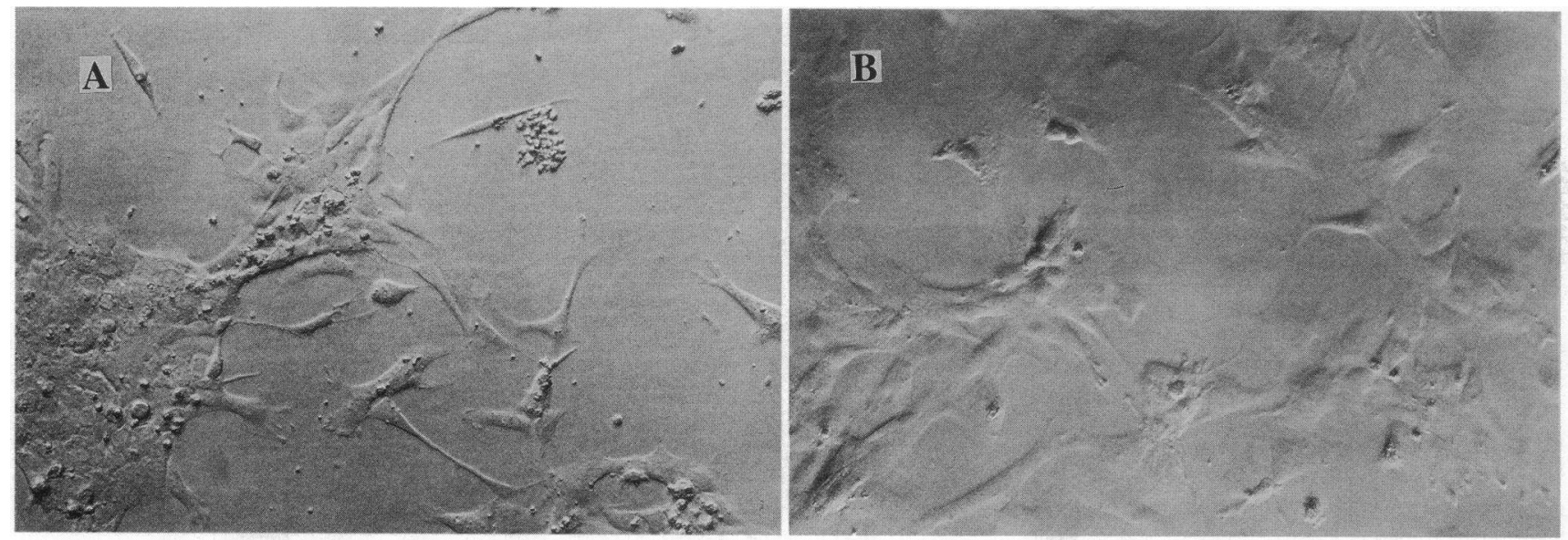

Figure 7. Sodium nitroprusside does not alter the morphology of cultured whole ovarian dispersates. Whole ovarian dispersates $\left(5 \times 10^{5}\right.$ viable cells/dish) were cultured for $96 \mathrm{~h}$ under serum-free conditions in the absence $(A)$ or presence $(B)$ of nitroprusside $(0.5 \mathrm{mM})$. Data reflect a representative experiment.

dose (0.5 mM) of aminoguanidine (vs. $0.4 \mathrm{mM}$, used herein) to reverse nitrite production. However, that same dose used $(0.4$ $\mathrm{mM}$ ) in our hands inhibits nitrite and nitrate production, 97 and $78 \%$, respectively (see Fig. 1). More importantly, our conclusion that NO does not mediate IL- $\beta$-induced cytotoxic/morphologic changes in the rat is based on several lines of evidence as discussed above, all of which are consistent with the conclusions reached.

It is well established that NO generated by iNOS of macrophage origin is an immunomodulator (26) with cytostatic, cytotoxic and mutagenic properties $(1,3)$. Furthermore, induction of NO by macrophage products (e.g., IL-1 $\beta$, tumor necrosis factor $\alpha$ ) has been demonstrated in a wide variety of tissues including cardiac myocytes (9), vascular smooth muscle (10), pancreatic islets $(11,12)$, chondrocytes $(27)$, and hepatocytes (28). The physiologic roles of iNOS in these non-macrophage tissues has yet to be elucidated and is not limited to a cytotoxic/ inflammatory response $(9,11,12)$. The recent suggestion that

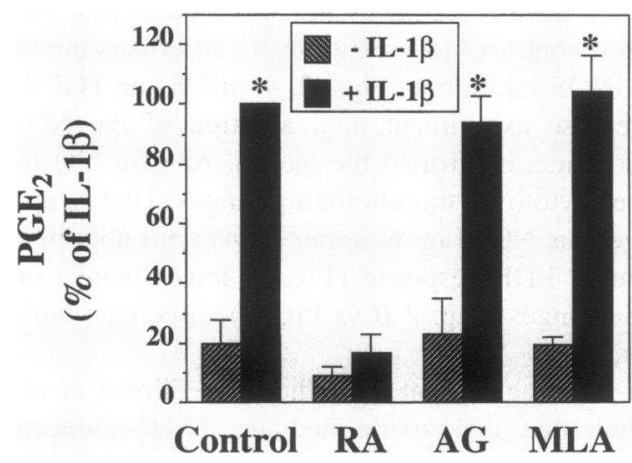

Figure 8 . NO does not mediate the ability of $\mathrm{IL}-1 \beta$ to stimulate prostaglandin $\mathrm{E}_{2}$ biosynthesis in cultured whole ovarian dispersates. Whole ovarian dispersates $\left(5 \times 10^{5}\right.$ viable cells/dish $)$ were cultured for $96 \mathrm{~h}$ under serum-free conditions in the absence or presence of IL-1 $\beta$ (50 $\mathrm{ng} / \mathrm{ml})$, with or without IL- $1 \beta \mathrm{RA}(5 \mu \mathrm{g} / \mathrm{ml})$, AG $(0.4 \mathrm{mM})$, or MLA $(0.4 \mathrm{mM})$. Media $\mathrm{PGE}_{2}$ content was determined by RIA as described in Methods. Data reflect the mean $\pm \mathrm{SE}$ of 3-7 experiments $(\mathrm{N}=2$ for MLA only) and are normalized as a percent of the value for IL-1 $\beta$ $(100 \%=4.7 \pm 1.1 \mathrm{ng} / \mathrm{ml})$. Significance by ANOVA analysis (relative to the $-\mathrm{IL}-1 \beta$ control) is noted $(*)$. cloned iNOS from human hepatocytes is a gene product distinct from both macrophage iNOS as well as brain and endothelial constitutive NOS (29) indicates that the functions of NO are varied and complex and that the action of cytokine-induced NOS in other tissues may not mimic those of macrophage iNOS. Indeed, our observation that IL- $1 \beta$-stimulated NO production does not mediate IL- $\beta$-induced morphogenic, cytotoxic, and inflammatory-like changes in resident ovarian cells suggests a different role for NO in this tissue. Similarly, Southern and Matthews (30) have shown that tumor necrosis factor-induced cytotoxicity and NO production in U937A cells are unrelated.

We have previously shown that $\mathrm{IL}-1 \beta$ mRNA is specifically expressed in the rat ovary just prior to ovulation (31). Since ovulation has been likened to an inflammatory or immune-response (32), perhaps it is not surprising that NO, a primary player in such responses, is evoked by IL- $1 \beta$. In this regard, we can only guess at a role for $\mathrm{NO}$ at the time of ovulation. One may speculate that $\mathrm{IL}-1 \beta$-stimulated NO generation may be involved with periovulatory changes in ovarian vascular dynamics (32) based on the established vasodilatory activity of this free radical.

\section{Acknowledgments}

I. Ben-Schlomo is a recipient of an International Fellowship Award from the Israeli Medical Association, a Lalor Foundation Fellowship Award, and a Harlea Charitable Trust Award (London). This work was supported in part by National Institutes of Health grants HD-30288 and HD-19998 (E. Y. Adashi).

\section{References}

1. Moncada, S., R. M. J. Palmer, and E. A. Higgs. 1991. Nitric oxide: physiology, pathophysiology, and pharmacology. Pharmacol. Rev. 43:109-142.

2. Lowenstein, C. J., and S. H. Synder. 1992. Nitric oxide: a novel biologic messenger. Cell. 70:705-707.

3. Culotta, E., and D. E. Koshland, Jr. 1992. NO news is good news. Science (Wash. DC). 258:1862-1863.

4. Stamler, J. S., D. J. Singel, and J. Loscalzo. 1992. Biochemistry of nitric oxide and its redox-activated forms. Science (Wash. DC). 258:1898-1902.

5. Sarih, M., V. Souvannavong, and A. Adam. 1993. Nitric oxide synthase induces macrophage death by apoptosis. Biochem. Biophys. Res. Commun. 191:503-508.

6. Nguyen, T., D. Branson, C. L., Crespi, B. W. Penman, J. S. Wishnok, and 
S. R. Tannenbaum. 1992. DNA damage and mutation in human cells exposed to nitric oxide in vitro. Proc. Natl. Acad. Sci. USA. 89:3030-3034.

7. Stuehr, D. J., and C. F. Nathan. 1989. Nitric oxide, a macrophage product responsible for cytostasis and respiratory inhibition in tumor target cells. J. Exp. Med. 169:1543-1555

8. Hibbs, J. B., R. R. Tainter, Z. Vavrin, and E. M. Rachlin. 1988. Nitric oxide: A cytotoxic activated macrophage effector molecule. Biochem. Biophys. Res. Commun. 157:87-94.

9. Roberts, A. B., Y. Vodovotz, N. S., Roche, M. B. Sporn, and C. F. Nathan. 1992. Role of nitric oxide in antagonistic effects of transforming growth factor$\beta$ and interleukin- $1 \beta$ on the beating rate of cultured cardiac myocytes. Mol. Endocrinol. 6:1921-1930.

10. Kilbourn, R. G., S. S. Gross, R. F. Lodato, J. Adams, R. Levi, L. L. Miller, L. B. Lachman, and O. W. Griffith. 1992. Inhibition of interleukin-1- $\alpha$ induced nitric oxide synthase in vascular smooth muscle and full reversal of interleukin-1- $\alpha$-induced hypotension by NW-amino-L-arginine. J. Natl. Cancer Inst. 84:1008-1016.

11. Eizirik, D. L., E. Cagliero, A. Bjorklund, and N. Welsh. 1992. Interleukin$1 \beta$ induces the expression of an isoform of nitric oxide synthase in insulinproducing cells which is similar to that observed in activated macrophages. FEBS (Fed. Eur. Biochem. Soc.). 308:249-252.

12. Corbett, J. A., M. A. Sweetland, J. L. Wang, J. A. Lancaster, Jr., and M. L. McDaniel. 1993. Nitric oxide mediates cytokine-induced inhibition of insulin secretion by human islets of Langerhans. Proc. Natl. Acad. Sci. USA. 90:1731 1735.

13. Hurwitz, A., E. R. Hernandez, D. W. Payne, A. M. Dharmarajan, and E. Y. Adashi. 1992. Interleukin-1 is both morphogenic and cytotoxic to cultured rat ovarian cells: obligatory role for heterologous, contact-independent cell-cell interaction. Endocrinology. 131:1643-1649.

14. Kokia, E., A. Hurwitz, E. Ricciarelli, C. Tedeschi, C. E. Resnick, M. D. Mitchell, and E. Y. Adashi. 1992. Interleukin-1 stimulates ovarian prostaglandin biosynthesis: evidence for heterologous contact-independent cell-cell interaction. Endocrinology. 130:3095-3097.

15. Ben-Shlomo, I., E. Kokia, M. J. Jackson, E. Y. Adashi, and D. W. Payne 1994. Interleukin-1 $\beta$ stimulates nitrite production in the rat ovary: Evidence for heterologous cell-cell interaction and for insulin-mediated regulation of the inducible isoform of nitric oxide syntase. Biol. Reprod. 51:In press.

16. Ellman, C., J. A. Corbett, T. P. Misko, M. McDaniel, and K. P. Beckerman 1993. Nitric oxide mediates interleukin-1-induced cellular cytotoxicity in the rat ovary: a potential role for nitric oxide in the ovulatory process. J. Clin. Invest. 92:3053-3056.

17. Carter, D. B., M. R. Diebel, Jr., C. J. Dunn, C. S. Tomich, A. C. Laborde J. L. Slighton, A. E. Berger, M. J. Bienkowski, S. I. Sun, R. N. McEwan, P. K. W. Harris, A. W. Yem, G. A. Waszak, J. G. Chosay, L. C. Sieu, M. M. Hardee, H. A. Zurcher-Neely, I. M. Reardon, R. L. Heinrikson, S. E. Truesdell, J. A Shelly, T. E. Eessalu, B. M. Taylor, and D. E. Tracey. 1990. Purification, cloning expression and biologic characterization of an interleukin-1 receptor antagonis protein. Nature (Lond.). 344:633-638.

18. Hurwitz, A., D. W. Payne, J. N. Packman, C. L. Andreani, C. E. Resnick,
E. R. Hernandez, and E. Y. Adashi. 1991. Cytokine-mediated regulation of ovarian function: interleukin-1 inhibits gonadotropin-induced androgen biosynthesis. En docrinology. 129:1250-1256.

19. Green, L. C., D. A. Wagner, J. Glogowski, P. L. Skipper, J. S. Wishnok, and S. R. Tannebaum. 1982. Analysis of nitrate, nitrite and [15N] nitrite in biological fluids. Anal. Biochem. 126:131-138.

20. Bartholemew, B. 1984. A rapid method for the assay of nitrate in urine using the nitrate reductase enzyme of Escherichia Coli. Biochem. Toxic. 22:541 543

21. Malinowska, D. H. 1990. Permeabilizing parietal cells. In Methods of Enzymology, S. Fleischer, and B. Fleischer B, editors. Academic Press, San Diego. 192:108-124.

22. Jaffe, B. M., H. R. Behrman, and C. W. Parker. 1973. Radioimmunoassay measurement of prostaglandins $\mathrm{E}, \mathrm{A}$, and $\mathrm{F}$ in human plasma. J. Clin. Invest. 52:398-405

23. Hibbs, J. B., Jr., Z. Vavrin, and R. R. Taintor. 1987. L-arginine is required for expression of the activated macrophage effector mechanism causing selective metabolic inhibition in target cells. J. Immunol. 138:550-565.

24. Gross, S. S., D. J. Stuehr, K. Aisaka, E. A. Jaffe, R. Levi, and O. W. Griffith. 1990. Macrophage and endothelial cell nitric oxide synthesis: Cell-type selective inhibition by NG-aminoarginine, NG-nitroarginine and NG-methylarginine. Biochem. Biophys. Res. Commun. 170:96-103.

25. Corbett, J. A., R. G. Tilton, K. Chang, K. S. Hasan, Y. Ido, J. L. Wang, M. A. Sweetland, J. R. Lancaster, Jr., J. R. Williamson, and M. L. McDaniel 1992. Aminoguanidine, a novel inhibitor of nitric oxide formation, prevents diabetic vascular dysfunction. Diabetes. 41:552-556.

26. Langrehr, J. M., R. A. Hoffman, J. R. Lancaster, Jr., and R. L. Simmons. 1993. Nitric oxide - a new endogenous immunodilator. Transplantation (Baltimore). 55:1205-1212.

27. Palmer, R. M. J., M. S. Hickey, I. G. Charles, S. Moncada, and M. T. Bayliss. 1993. Induction of nitric oxide synthase in human chondrocytes. Biochem. Biophys. Res. Commun. 193:398-405.

28. Geller, D. A., A. K. Nussler, M. DiSilvio, C. J. Lowenstein, R. A. Shapiro, S. C. Wang, R. Simmons, and T. R. Billiar. 1993. Cytokines, endotoxin and glucocorticoids regulate the expression of inducible nitric oxide synthase in hepatocytes. Proc. Natl. Acad. Sci. USA. 90:522-526.

29. Geller, D. A., C. J. Lowenstein, R. A. Shapiro, A. K. Nussler, M. DiSilvio S. C. Wang, D. K. Nakayama, R. L. Simmons, S. H. Snyder, and T. R. Billiar 1993. Molecular cloning and expression of inducible nitric oxide synthase from human hepatocytes. Proc. Natl. Acad. Sci. USA. 90:3491-3495.

30. Southern, C., and N. Matthews. 1993. Nitric oxide is produced during TNF killing of U937A cells but does not contribute to the cytotoxic process. Biochem. Biophys. Res. Commun. 1177:179-182.

31. Hurwitz, A., E. Ricciarelli, L. F. Botero, R. M. Rohan, E. R. Hernandez, and $\mathrm{E}, \mathrm{Y}$. Adashi. 1991. Endocrine- and autocrine-mediated regulation of rat ovarian (theca-interstitial) interleukin- $\beta$ gene expression: Gonadotropin-dependent pre-ovulatory acquisition. Endocrinology. 129:3427-3429.

32. Espey, L. L. 1980. Ovulation as an inflammatory reaction-A hypothesis. Biol. Reprod. 22:73-106. 